\title{
EFFECT OF THERMOMECHANICAL TREATMENT ON THE CORROSION BEHAVIOUR OF Si- AND Al-CONTAINING HIGH-Mn AUSTENITIC STEEL WITH Nb AND Ti MICRO-ADDITIONS
}

\author{
VPLIV TERMOMEHANSKE OBDELAVE NA KOROZIJSKO \\ VEDENJE MANGANSKEGA AVSTENITNEGA JEKLA Z \\ VSEBNOSTJO Si IN Al, MIKROLEGIRANEGA Z Nb IN Ti
}

\author{
Adam Grajcar, Aleksandra Plachcińska, Santina Topolska, Monika Kciuk \\ Silesian University of Technology, Institute of Engineering Materials and Biomaterials, Konarskiego Street 18a, 44-100 Gliwice, Poland \\ adam.grajcar@polsl.pl
}

Prejem rokopisa - received: 2014-07-31; sprejem za objavo - accepted for publication: 2014-12-19

doi: $10.17222 / \mathrm{mit} .2014 .148$

The corrosion behavior of the $27 \mathrm{Mn}-4 \mathrm{Si}-2 \mathrm{Al}$ type austenitic steel micro-alloyed with $\mathrm{Nb}$ and Ti was evaluated in acidic $0.1 \mathrm{M}$ $\mathrm{H}_{2} \mathrm{SO}_{4}$ and chloride $3.5 \% \mathrm{NaCl}$ environments using potentiodynamic polarization tests. The corrosion properties of solution-treated specimens were compared to thermomechanically processed specimens. In the acidic solution, the steel exhibited a lower corrosion resistance than in the chloride solution, independently of the heat treatment applied. SEM and light micrographs confirmed that the corrosion attack in the acidic solution was higher when compared to the chloride solution. The steel showed evidence of pitting and uniform corrosion in both the acidic and chloride solutions. The corrosion resistance of supersaturated specimens in both $0.1 \mathrm{M} \mathrm{H}_{2} \mathrm{SO}_{4}$ and $3.5 \% \mathrm{NaCl}$ media was lower when compared to the thermomechanically treated specimens. It was found that the corrosion behavior of the examined high-Mn steel depends on the passivation tendency of the alloying elements $(\mathrm{Mn}, \mathrm{Al})$ and the grain size.

Keywords: high-Mn steel, austenitic steel, corrosion resistance, passivity, thermomechanical treatment, potentiodynamic polarization test

Korozijsko vedenje avstenitnega jekla $27 \mathrm{Mn}-4 \mathrm{Si}-2 \mathrm{Al}$, mikrolegiranega $\mathrm{z} \mathrm{Nb}$ in Ti je bilo ocenjeno v kislem $0,1 \mathrm{M} \mathrm{H}_{2} \mathrm{SO}_{4}$ in v kloridnem okolju 3,5\% NaCl, s potenciodinamičnim polarizacijskim preizkusom. Korozijske lastnosti raztopno žarjenih vzorcev so bile primerjane s termomehansko izdelanimi vzorci. V kisli raztopini so bili vzorci manj korozijsko odporni kot v kloridni raztopini, neodvisno od uporabljene toplotne obdelave. SEM in svetlobni posnetki so potrdili, da je bil napad korozije v primerjavi s kloridno raztopino izrazitejši v kisli raztopini. Na jeklu so bili dokazi za jamičasto in splošno korozijo v obeh raztopinah, kisli in bazični. Korozijska odpornost prenasičenih vzorcev v $0,1 \mathrm{M} \mathrm{H}_{2} \mathrm{SO}_{4}$ in $\mathrm{v} 3,5 \% \mathrm{NaCl}$ je bila manjša $\mathrm{v}$ primerjavi s termomehansko obdelanimi vzorci. Ugotovljeno je, da je korozijsko vedenje preiskovanega visokomanganskega jekla odvisno od nagnjenosti k pasivaciji legirnih elementov (Mn, Al) in od velikosti zrn.

Ključne besede: visokomangansko jeklo, avstenitno jeklo, korozijska odpornost, pasivnost, termomehanska obdelava, preizkus potenciodinamične polarizacije

\section{INTRODUCTION}

High-manganese austenitic steels are being developed as advanced automotive structural materials due to their superior combination of strength, ductility, and crashworthiness. However, their application for automotive parts is limited because of their low corrosion resistance. The corrosion behavior of high-manganese austenitic steels depends on their chemical composition and the corrosion medium applied. It was found that additions of $\mathrm{Al}$ and $\mathrm{Cr}$ improve the corrosion resistance of high-Mn steels. ${ }^{1-3}$ This is due to the passive-filmforming tendency of the steel surface. It is reported that a silicon addition to steel decreases its corrosion resistance. ${ }^{4}$ The tendency to create a passive protective layer on the steel surface depends on the type of corrosive environment. Kannan et al. ${ }^{1}$ reported that 29Mn-3.1Al-1.4Si austenitic steel showed a lower corro- sion resistance in an acidic solution than in a chloride solution.

The corrosion behavior of high-Mn austenitic steels also depends on the heat treatment applied and plastic deformation. Generally, cold working increases the corrosion rate because of the deformation twins, which represent the regions of different potentials from the matrix. ${ }^{5,6}$ The corrosion resistance of steel is also related to the dislocation density. In cold-rolled steels the dislocation amount is much higher when compared to hot-rolled steels because of the recrystallization effects reducing the dislocation density. ${ }^{7-9}$ The corrosion resistance of grain boundaries is poor because of a high dislocation density present at these regions. Di Schino et al. ${ }^{10}$ reported that the corrosion resistance of steel is also related to its grain size.

During the past decade, there were a number of reports on the corrosion properties of Fe-(high-Mn)- 
Al-Si alloys. Most investigations focused on the effect of the alloying elements on the corrosion behaviour. There are few reports about the effects of heat treatment or plastic deformation on the corrosion resistance of highMn austenitic steels. ${ }^{5,11}$ Therefore, the corrosion properties of solution-treated and thermomechanically processed specimens were compared in this work.

\section{EXPERIMENTAL PROCEDURE}

The work addresses the corrosion behaviour of the vacuum-melted high-manganese steel containing $0.04 \%$ C, $27.5 \% \mathrm{Mn}, 4.18 \% \mathrm{Si}, 1.96 \% \mathrm{Al}, 0.017 \% \mathrm{~S}$, $0.004 \% \mathrm{P}$ and $0.0028 \% \mathrm{~N}$. Carbon and manganese are the main austenite stabilizers. Silicon and aluminium should provide solid-solution strengthening. Additionally, micro-additions of $\mathrm{Nb}(0.033 \%)$ and $\mathrm{Ti}(0.01 \%)$ are added for precipitation strengthening and grain refinement. The ingots were hot forged and roughly rolled to a thickness of $4.5 \mathrm{~mm}$. Two types of specimens were prepared using the thermomechanical rolling and the subsequent solution treatment. The thermomechanical processing consisted of hot rolling of flat samples in 3 passes to a final thickness of about $2 \mathrm{~mm}$ obtained at the finishing rolling temperature of $850{ }^{\circ} \mathrm{C}$. Then, the samples were rapidly cooled in water to room temperature. The second group of samples was subsequently annealed at $900{ }^{\circ} \mathrm{C}$ for $20 \mathrm{~min}$.

The corrosion properties of the $27 \mathrm{Mn}-4 \mathrm{Si}-2 \mathrm{Al}$ steel were evaluated using potentiodynamic polarization tests in two environments: acidic $0.1 \mathrm{M} \mathrm{H}_{2} \mathrm{SO}_{4}$ and $3.5 \%$ $\mathrm{NaCl}$ solutions. The corrosion behavior of the solutiontreated specimens was compared to the thermomechanically processed specimens. The corrosion tests were examined using the average of the measurement results for four supersaturated and two thermomechanically treated specimens. The exposed specimen surfaces $\left(0.38 \mathrm{~cm}^{2}\right)$ were ground with $\mathrm{SiC}$ paper of up to 800 grit. The samples were washed in distilled water and rinsed in acetone before the experiments. All the corrosion tests were conducted using freshly prepared electrolytes. Polarization studies were carried out using an Atlas 0531 electrochemical unit potentiostat/galvanostat driven by the AtlasCorr05 software and an electrochemical corrosion cell consisting of a specimen as the working electrode, stainless steel as the counter electrode and a silver/silver chloride $(\mathrm{Ag} / \mathrm{AgCl})$ reference electrode. A scan rate of $0.5 \mathrm{mV} / \mathrm{s}$ was employed during polarization. Potentiodynamic-scan data were collected to determine the electrochemical parameters - corrosion potential $E_{\text {corr }}$ and corrosion current density $i_{\text {corr }}-$ using Tafel slope extrapolation.

After the polarization tests, the samples were observed using a Zeiss SUPRA 25 scanning electron microscope (SEM) to assess the type of the corrosion attack. Subsequently, the depth of the corrosion pits on the cross-sectioned specimens using a Zeiss Axio Ob- server $\mathrm{Z} 1 \mathrm{~m}$ light microscope was evaluated. For light microscopy, the samples were mechanically ground with $\mathrm{SiC}$ paper of up to 1500 grit, polished with $\mathrm{Al}_{2} \mathrm{O}_{3}$ with a granularity of $0.1 \mu \mathrm{m}$ and then etched using $5 \%$ nital to reveal the microstructure.

\section{RESULTS AND DISCUSSION}

A typical micrograph of a thermomechanically treated specimen is shown in Figure 1a. The light micrograph presents relatively coarse austenite grains elongated in the direction of hot rolling. The average grain size was estimated to be about $70 \mu \mathrm{m}$. Annealing twins and elongated sulfide inclusions were also observed. Figure $\mathbf{1 b}$ shows the light micrograph of a solution-treated specimen. The microstructure of the steel solution-treated from a temperature of $900{ }^{\circ} \mathrm{C}$ is characterized by a bimodal distribution of the grains. The average grain size was estimated to be about $40 \mu \mathrm{m}$. Relatively large elongated austenite grains and small recrystallized grains are apparent, indicating a strain accumulation that remains after the thermomechanical rolling. As a result, the driving force decreasing the accumulated energy leads to a partial recrystallization of

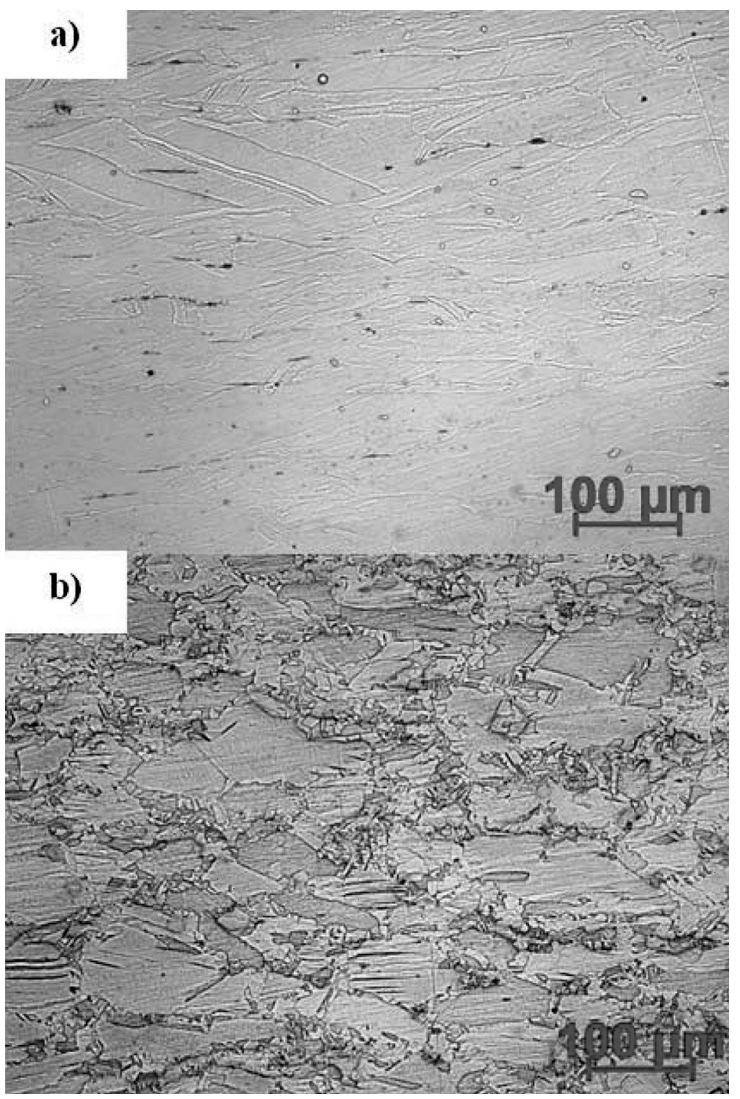

Figure 1: Austenitic microstructures of: a) thermomechanically treated and b) supersaturated steels

Slika 1: Avstenitna mikrostruktura: a) termomehansko obdelanega in b) prenasičenega jekla 
the austenite grains during the subsequent annealing of the samples at $900{ }^{\circ} \mathrm{C}$.

Based on the potentiodynamic curves (Figures 2 to 5), the corrosion potential $E_{\text {corr }}$ and corrosion current density $i_{\text {corr }}$ were determined. The average calculated values are shown in Table 1. The results of the corrosion tests are characterized by a small scatter. The lowest corrosion resistance was obtained in the acidic solution, independently of the heat-treatment type (thermomechanically treated or supersaturated specimens). The highest values of the corrosion current density were registered in the acidic solution. Kannan et al. ${ }^{1}$ also reported that the 29Mn-3.1Al-1.4Si austenitic steel showed a lower corrosion resistance in an acidic medium than in a chloride solution.

Table 1: Electrochemical-polarization data of thermomechanically treated (t) and supersaturated (s) steels in two different environments Tabela 1: Podatki o elektrokemijski polarizaciji termomehansko obdelanega (t) in prenasičenega (s) jekla $\mathrm{v}$ dveh različnih okoljih

\begin{tabular}{|c|c|c|c|c|c|}
\hline & \multirow{2}{*}{$\begin{array}{c}\text { Type of } \\
\text { heat } \\
\text { treatment }\end{array}$} & \multicolumn{2}{|c|}{$3.5 \% \mathrm{NaCl}$} & \multicolumn{2}{|c|}{$0.1 \mathrm{M} \mathrm{H}_{2} \mathrm{SO}_{4}$} \\
\hline & & $\begin{array}{c}E_{\text {corr }} / \\
\mathrm{mV}\end{array}$ & $\begin{array}{c}i_{\text {corr }} / \\
\mathrm{mA} / \mathrm{cm}^{2}\end{array}$ & $\begin{array}{c}E_{\text {corrl }} / \\
\mathrm{mV}\end{array}$ & $\begin{array}{c}i_{\text {corr }} / \\
\mathrm{mA} / \mathrm{cm}^{2}\end{array}$ \\
\hline $\begin{array}{c}\text { average } \\
\text { value }\end{array}$ & \multirow[b]{2}{*}{$\mathrm{s}$} & -774.4 & 0.30 & -584.7 & 12.3 \\
\hline $\begin{array}{l}\text { standard } \\
\text { deviation }\end{array}$ & & 29.1 & 0.05 & 8.8 & 1.5 \\
\hline $\begin{array}{c}\text { average } \\
\text { value }\end{array}$ & \multirow[b]{2}{*}{$\mathrm{t}$} & -787.6 & 0.09 & -583.9 & 1.4 \\
\hline $\begin{array}{l}\text { standard } \\
\text { deviation }\end{array}$ & & 6.5 & 0.007 & 6.2 & 0.2 \\
\hline
\end{tabular}

The solution-treated specimens showed a higher corrosion-current-density values $\left(12.29 \mathrm{~mA} / \mathrm{cm}^{2}\right)$ than the thermomechanically treated specimens $\left(1.44 \mathrm{~mA} / \mathrm{cm}^{2}\right)$. In the chloride solution, the supersaturated specimens also showed a higher corrosion current density $(0.24$ $\mathrm{mA} / \mathrm{cm}^{2}$ ) when compared to the thermomechanically treated specimens $\left(0.09 \mathrm{~mA} / \mathrm{cm}^{2}\right)$. Generally, it is re-

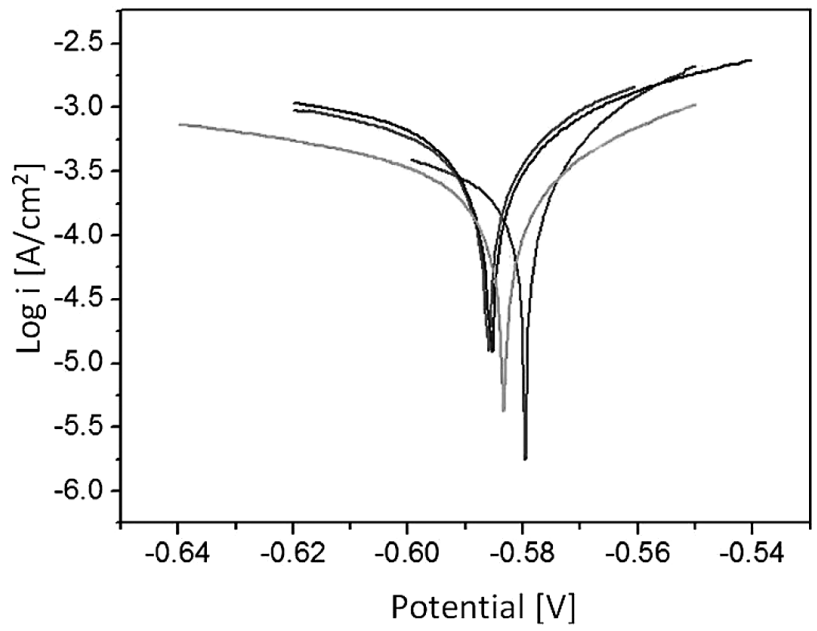

Figure 2: Potentiodynamic-polarization curves of the supersaturated steel obtained in $0.1 \mathrm{M} \mathrm{H}_{2} \mathrm{SO}_{4}$ solution (4 samples tested)

Slika 2: Potenciodinamične polarizacijske krivulje prenasičenega jekla, posnete v raztopini $0,1 \mathrm{M} \mathrm{H}_{2} \mathrm{SO}_{4}$ (preizkušeni so bili 4 vzorci)

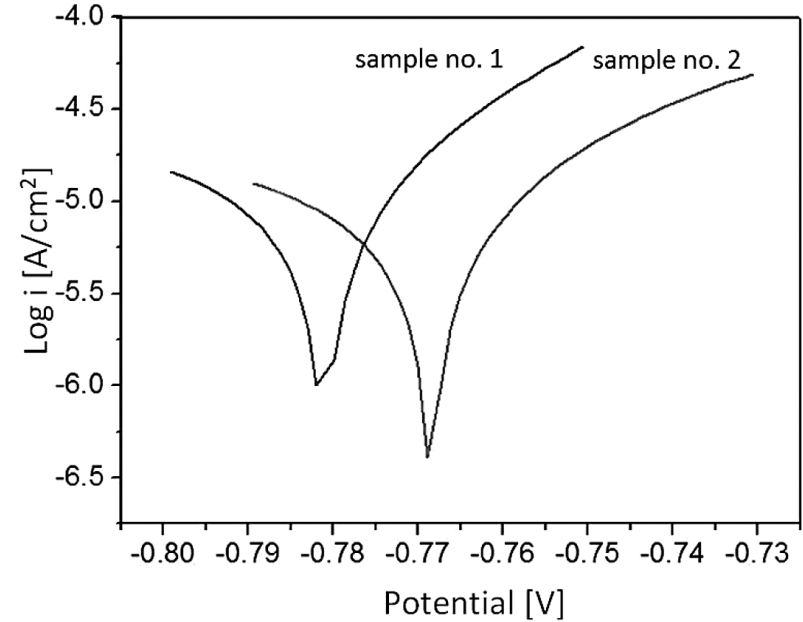

Figure 3: Potentiodynamic-polarization curves of the thermomechanically treated steel obtained in $3.5 \% \mathrm{NaCl}$ solution (2 samples tested)

Slika 3: Potenciodinamični polarizacijski krivulji termomehansko obdelanega jekla, posneti v raztopini $3,5 \% \mathrm{NaCl}$ (preizkušena sta bila 2 vzorca)

ported that cold working decreases the corrosion resistance of steel. ${ }^{5,6}$ Interestingly, the thermomechanically treated specimens showed a higher corrosion resistance than the supersaturated specimens independently of the corrosion medium. It should be noted that the examined steel was hot rolled. Hence, it has a much lower dislocation density than the cold-rolled specimens. Therefore, the higher corrosion resistance of the thermomechanically treated specimens is related to other factors.

The corrosion-potential values of the thermomechanically treated and supersaturated specimens are similar in both the acidic (Figure 2) and chloride solutions (Figure 3). The lowest corrosion-potential values were

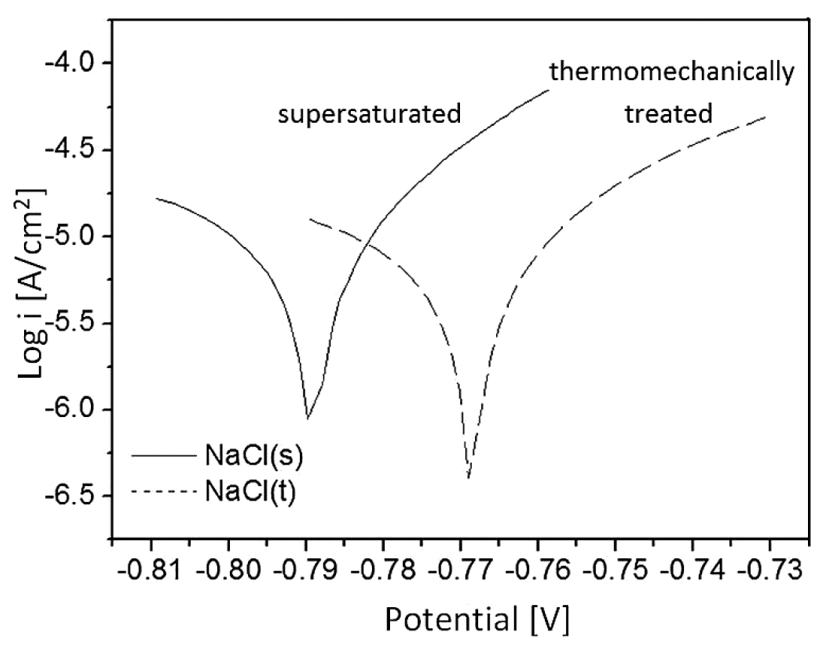

Figure 4: Potentiodynamic-polarization curves of the thermomechanically treated $(\mathrm{t})$ and supersaturated (s) steels obtained in $3.5 \% \mathrm{NaCl}$ solution

Slika 4: Potenciodinamični polarizacijski krivulji termomehansko obdelanega $(\mathrm{t})$ in prenasičenega (s) jekla, posneti $\mathrm{v}$ raztopini $3,5 \%$ $\mathrm{NaCl}$ 
A. GRAJCAR et al.: EFFECT OF THERMOMECHANICAL TREATMENT ON THE CORROSION BEHAVIOUR ...

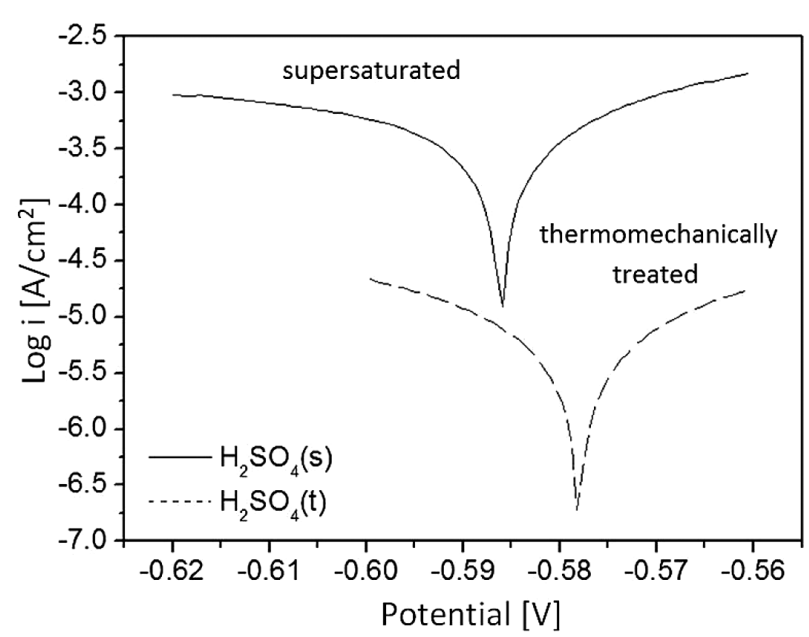

Figure 5: Potentiodynamic-polarization curves of the thermomechanically treated $(\mathrm{t})$ and supersaturated $(\mathrm{s})$ steels obtained in $0.1 \mathrm{M}$ $\mathrm{H}_{2} \mathrm{SO}_{4}$ solution

Slika 5: Potenciodinamični polarizacijski krivulji termomehansko obdelanega (t) in prenasičenega (s) jekla, posneti $\mathrm{v}$ raztopini $0,1 \mathrm{M}$ $\mathrm{H}_{2} \mathrm{SO}_{4}$

registered in the chloride solution (Figure 4). They are related to the earlier appearance of the corrosion pits in the chloride environment. In the $0.1 \mathrm{M} \mathrm{H}_{2} \mathrm{SO}_{4}$ medium,
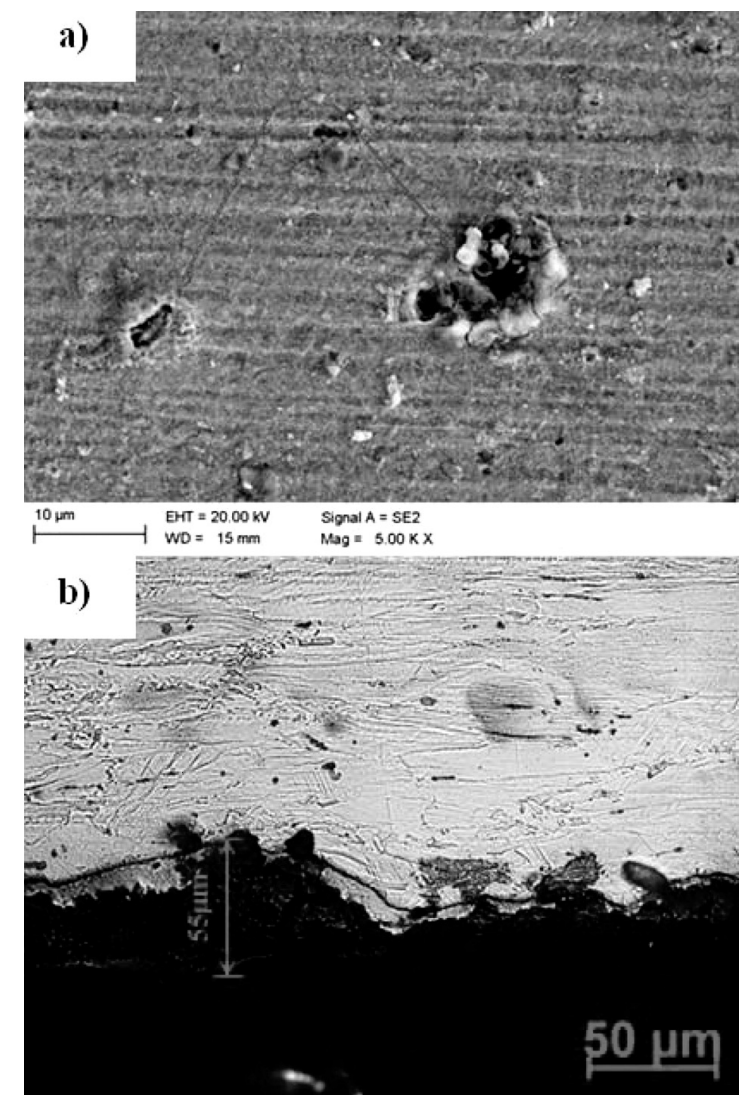

Figure 6: a) SEM micrograph of the surface and b) light micrograph of the cross-section of thermomechanically treated steel specimens, potentiodynamically polarized in acidic solution

Slika 6: a) SEM-posnetek površine in b) svetlobni posnetek prečnega prereza termomehansko obdelanega vzorca jekla, potenciodinamično polariziranega $\mathrm{v}$ kisli raztopini higher (right-shifted) corrosion-potential values were registered (Figure 5). The lowest values of the corrosion potential in the chloride solution are also reported for the other high-Mn alloys. ${ }^{1}$ However, it should be noted that the values of the corrosion current density were much higher in the acidic solution (Table 1). They are related to the stronger corrosion attack in this medium.

The SEM and light micrographs of the thermomechanically treated and supersaturated specimens after the polarization tests in two environments are shown in Figures 6 to 8. In the acidic solution, both steels showed extensive uniform corrosion. In addition to uniform corrosion, pitting corrosion can also be observed (Figure 6). In the thermomechanically treated specimens, after the corrosion tests in $0.1 \mathrm{M} \mathrm{H}_{2} \mathrm{SO}_{4}$ the maximum depth of corrosion pits was evaluated as $55 \mu \mathrm{m}$ (Figure 6b). In the supersaturated specimens, the maximum depth of corrosion pits was slightly higher (Figure $7 \mathbf{b}$ ). On both types of specimens, wide and shallow corrosion pits were observed. It was noted that corrosion pits were usually formed in the coarse-grained regions of the microstructure. Fine-grained regions were dominated by uniform corrosion and a smaller density of the corrosion pits. A similar relationship between the corrosion resis-
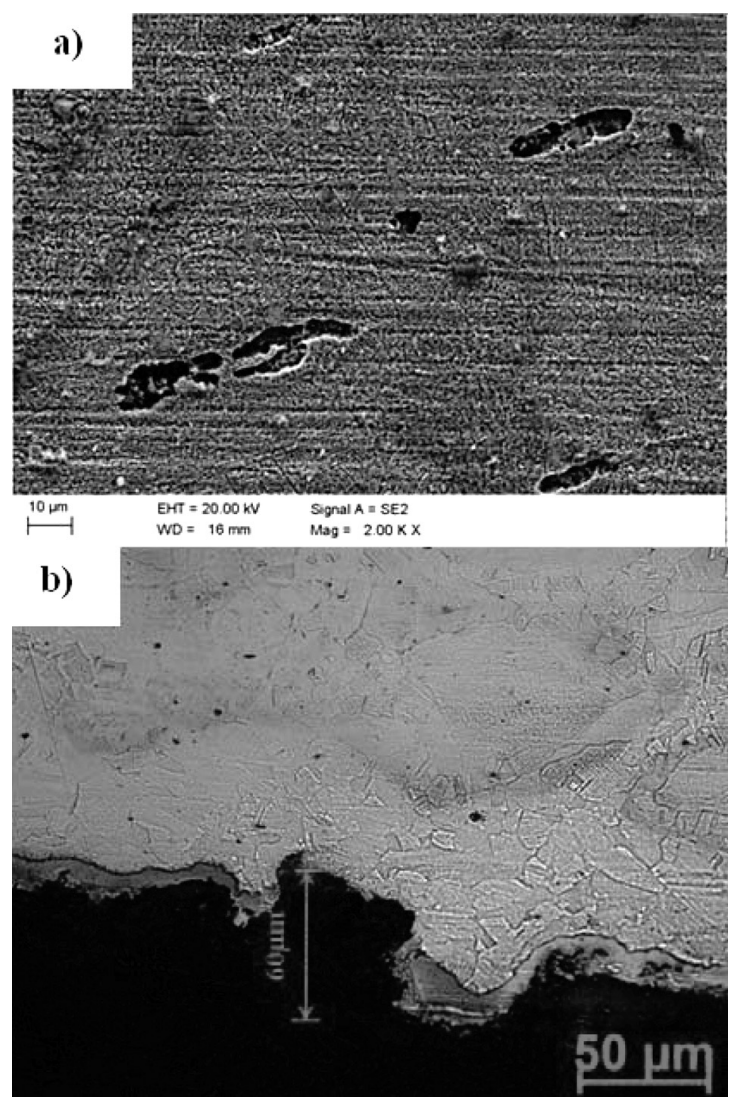

Figure 7: a) SEM micrograph of the surface and b) light micrograph of the cross-section of supersaturated steel specimens, potentiodynamically polarized in acidic solution

Slika 7: a) SEM-posnetek površine in b) svetlobni posnetek prečnega prereza prenasičenega vzorca jekla, potenciodinamično polariziranega v kisli raztopini 

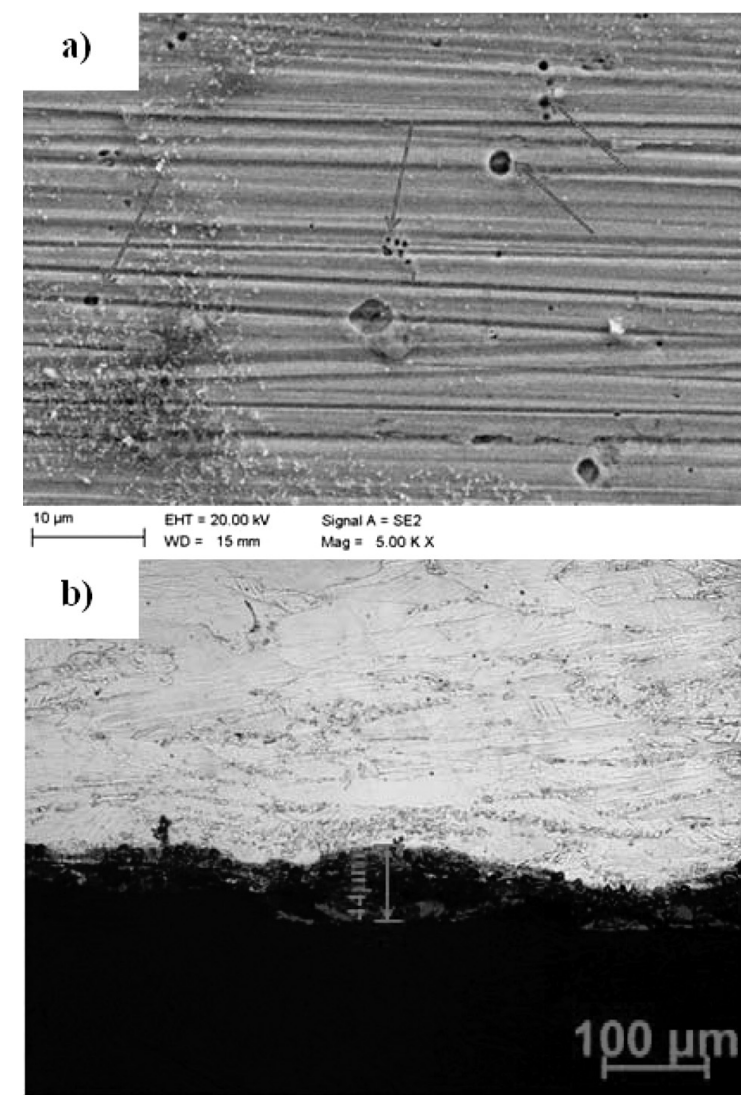

Figure 8: a) SEM micrograph of the surface and b) light micrograph of the cross-section of thermomechanically treated steel specimens, potentiodynamically polarized in chloride solution

Slika 8: a) SEM-posnetek površine in b) svetlobni posnetek prečnega prereza termomehansko obdelanega vzorca jekla, potenciodinamično polariziranega $\mathrm{v}$ raztopini klorida

tance and grain size was observed earlier by Di Schino et al. ${ }^{10}$ They observed that the pitting-corrosion rate decreased with the decreasing grain size, while the uniform-corrosion resistance was impaired by grain refining.

In the chloride solution, the thermomechanically treated specimens showed uniform corrosion. In addition to uniform corrosion, pitting-corrosion evidence was also observed (Figure 8a). Other authors ${ }^{1,12,13}$ also observed corrosion pits in different high-manganese steels after the polarization tests in a chloride solution. After the corrosion tests in $3.5 \% \mathrm{NaCl}$, the maximum depth of the corrosion pits of the thermomechanically treated specimens was evaluated as $44 \mu \mathrm{m}$ (Figure 8b). Similar corrosion pits can also be identified for the supersaturated specimens. Small pits are usually formed at nonmetallic inclusions (Figure 9). The same nature of corrosion damages of high-Mn steels was also observed by Grajcar et al. $^{6}$ on the samples subjected to immersion tests.

It was observed that pitting corrosion was usually initiated at sulfide inclusions. The negative impact of $\mathrm{MnS}$ inclusions on the corrosion resistance of austenitic steels was also observed by Donik et al. ${ }^{14}$ The density of
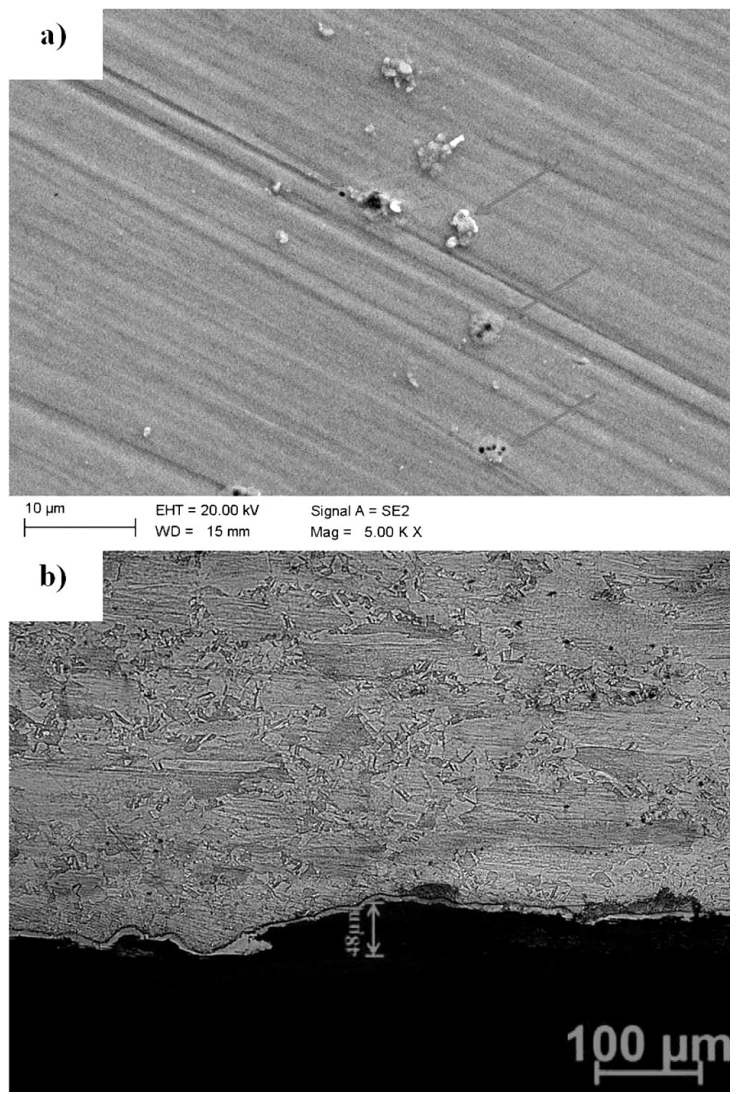

Figure 9: a) SEM micrograph of the surface and b) light micrograph of the cross-section of supersaturated steel specimens, potentiodynamically polarized in chloride solution

Slika 9: a) SEM-posnetek površine in b) svetlobni posnetek prečnega prereza prenasičenega vzorca jekla, potenciodinamično polariziranega $\mathrm{v}$ raztopini klorida

corrosion pits and corrosion products are greater in the acidic solution than in the chloride medium. Microscopic observations are confirmed by the potentiodynamic test results, which showed that the investigated steel has a better corrosion resistance in the chloride medium when compared to the acidic environment.

Corrosion resistance depends on the $\mathrm{pH}$ of corrosion solutions and the values of the corrosion potential (Pourbaix diagrams). ${ }^{15}$ In the $0.1 \mathrm{M} \mathrm{H}_{2} \mathrm{SO}_{4}(\mathrm{pH}=1)$ and $3.5 \%$ $\mathrm{NaCl}$ solutions, manganese dissolves as $\mathrm{Mn}^{2+}$. It can be concluded that $\mathrm{Mn}$ showed a non-passivating tendency in these environments. In the acidic solution, aluminium dissolves as $\mathrm{Al}^{3+}$ ions, preventing the formation of the passive layer. In the $3.5 \% \mathrm{NaCl}$ solution, aluminium forms the oxide passive layer, slightly increasing the corrosion resistance of the investigated steel.

\section{CONCLUSIONS}

Potentiodynamic polarization tests showed that the $27 \mathrm{Mn}-4 \mathrm{Si}-2 \mathrm{Al}$ type austenitic steel is characterized by the lowest corrosion resistance in the $0.1 \mathrm{M} \mathrm{H}_{2} \mathrm{SO}_{4}$ solution, independently of the heat treatment applied (thermomechanically treated or solution-treated specimens). 
Microscopic observations confirmed that corrosion damages are more numerous in the acidic solution. In both the acidic and chloride solutions wide and shallow corrosion pits of various depths were identified. In addition to pitting corrosion, extensive uniform corrosion was observed. The high density of the corrosion damages in the acidic solution is related to the non-passivating tendency of $\mathrm{Mn}$ and $\mathrm{Al}$ in this environment. Independently of the corrosion media, the thermomechanically treated specimens showed a better corrosion resistance than the supersaturated specimens. This means that the bimodal distribution of the grain size has a greater effect on decreasing the corrosion resistance of the investigated steel than the effect of hot working.

\section{REFERENCES}

${ }^{1}$ M. B. Kannan, R. K. S. Raman, S. Khoddam, Corros. Sci., 50 (2008), 2879-2884, doi:10.1016/j.corsci.2008.07.024

${ }^{2}$ V. F. C. Lins, M. A. Freitas, E. M. P. Silva, Appl. Surf. Sci., 250 (2005), 124-134, doi:10.1016/j.apsusc.2004.12.040

${ }^{3}$ Y. S. Zhang, X. M. Zhu, S. H. Zhong, Corros. Sci., 46 (2004), 853-876, doi:10.1016/j.corsci.2003.09.002
${ }^{4}$ S. Suzuki, E. Matsubara, T. Komatasu, Y. Okamoto, K. Kanie, A. Muramatsu, H. Konishi, J. Mizuki, Y. Waseda, Corros. Sci., 49 (2007), 1081-1096, doi:10.1016/j.corsci.2006.06.029

${ }^{5}$ I. M. Ghayad, A. S. Hamada, N. N. Girgis, W. A. Ghanem, Steel Grips, 4 (2006) 4, 133-137

${ }^{6}$ A. Grajcar, S. Kolodziej, W. Krukiewicz, Arch. Mater. Sci. Eng., 41 (2010) 2, 77-84

${ }^{7}$ A. Grajcar, M. Opiela, G. Fojt-Dymara, Arch. Civ. Mech. Eng., 9 (2009) 3, 49-58, doi:10.1016/S1644-9665(12)60217-9

${ }^{8}$ L. A. Dobrzański, A. Grajcar, W. Borek, Mater. Sci. Forum, 638-642 (2010), 3224-3229, doi:10.4028/MSF.638-642.3224

${ }^{9}$ G. R. Razavi, M. S. Rizi, H. M. Zadeh, Mater. Tehnol., 47 (2013) 5, 611-614

${ }^{10}$ A. Di Schino, M. Barteri, J. M. Kenny, J. Mater. Sci., 38 (2003) 15, 3257-3262, doi:10.1023/A:1025181820252

${ }^{11}$ S. Lasek, E. Mazancova, Metalurgija, 52 (2013), 441-444

${ }^{12}$ L. M. Roncery, S. Weber, W. Theisen, Metall. Mater. Trans. A, 41 (2010), 2471-2478, doi:10.1007/s11661-010-0334-Z

${ }^{13}$ Y. S. Zhang, X. M. Zhu, Corros. Sci., 41 (1999) 9, 1817-1833, doi:10.1016/S0010-938X(99)00017-7

${ }^{14}$ C. Donik, I. Paulin, M. Jenko, Mater. Tehnol., 44 (2010) 2, 67-72

${ }^{15}$ N. Takeno, Atlas of Eh-pH diagrams, National Institute of Advanced Science and Technology, Tokyo 2005 